\title{
SEEN BUT NOT SEEN
}

\section{Influential Canadians and the First Nations}

from the 1840s to Today

Throughout the nineteenth and most of the twentieth centuries, the majority of Canadians argued that European "civilization" must replace Indigenous culture. The ultimate objective was assimilation into the dominant society.

Seen but Not Seen explores the history of Indigenous marginalization and why non-Indigenous Canadians failed to recognize Indigenous societies and cultures as worthy of respect. Approaching the issue biographically, Donald B. Smith presents the commentaries of sixteen influential Canadians - including John A. Macdonald, George Grant, and Emily Carr - who spoke extensively on Indigenous subjects. Supported by documentary records spanning over nearly two centuries, Seen but Not Seen covers fresh ground in the history of settler-Indigenous relations.

DONALD B. SMITH is a professor emeritus of history at the University of Calgary. 


\section{About the Cover Illustration}

On 25 June 1969 the Liberal government of Pierre Trudeau tabled in the House of Commons the "Statement of the Government of Canada on Indian policy," popularly called "The White Paper" (in government, the term "white paper" is applied to policy proposals). If passed by Parliament, the new legislation would end the unique legal rights of status Indians. Reserves and the historic Indian treaties, as well as the Department of Indian Affairs and Northern Development itself, would disappear. Indigenous protest against the policy initiative arose immediately. Provincial and territorial First Nations political associations across Canada joined the National Indian Brotherhood (NIB; founded in 1968 and reorganized in 1982 as the Assembly of First Nations) to oppose it. Walter Deiter, a former chief of the Federation of Saskatchewan Indians and the NIB's founding president, led the fight against the attempt to end the special status of the First Nations.

On 4 June 1970 a phalanx of western chiefs, some dressed in traditional regalia, stood face to face with the prime minister and his full cabinet in the cavernous Railway Committee Room of the Parliament Buildings. Indian Association of Alberta (IAA) members Chiefs John Snow and Adam Soloway handed the position paper originally prepared by the IAA - entitled Citizens Plus but popularly known as "The Red Paper" to the prime minister. Then Harold Cardinal, IAA President, spoke on the significance of treaty and Aboriginal rights. In response to strong First Nations' protests against the assimilationist White Paper, the federal government formally retracted it in 1971.

Rudy Platiel, a retired Toronto Globe and Mail reporter, witnessed the Red Paper's submission. Half a century later, he recalled: "In 1970 I was assigned by The Globe and Mail to travel for a year across Canada to write about the situation of Indigenous people - then called Indians. Despite the now continued existence of systemic racism, the march of Indigenous rights and their reality today is light years beyond anything I actually thought possible back then. This progress gives hope that despite our human flaws and occasional cruelty, as a nation we may one day yet reach a new dawn of acceptance and cooperation between two societies that at times seems so tantalizingly far beyond us today. There is indeed hope."

The image shows Prime Minister Trudeau and his Minister of Indian Affairs, Jean Chrétien, facing NIB President Walter Deiter. 


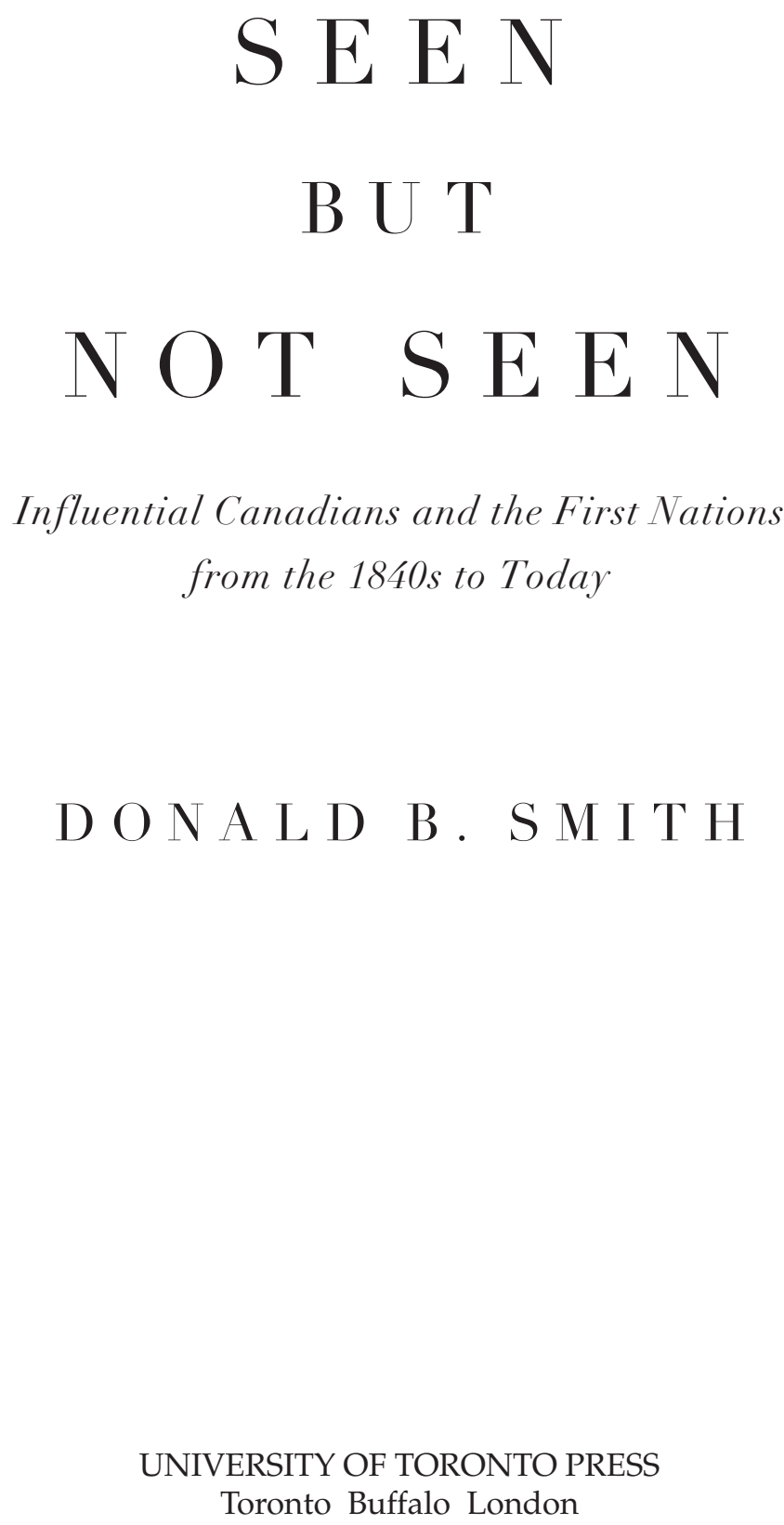


(C) University of Toronto Press 2021

Toronto Buffalo London

utorontopress.com

Printed in Canada

ISBN 978-1-4426-4998-9 (cloth) ISBN 978-1-4426-2212-8 (ePUB)

ISBN 978-1-4426-2770-3 (paper) ISBN 978-1-4426-2211-1 (PDF)

\section{Library and Archives Canada Cataloguing in Publication}

Title: Seen but not seen : influential Canadians and the First Nations from the 1840s to today / Donald B. Smith.

Names: Smith, Donald B., author.

Description: Includes bibliographical references and index.

Identifiers: Canadiana (print) 2020034644X | Canadiana (ebook) 20200346539 | ISBN 9781442649989 (hardcover) | ISBN 9781442627703

(softcover) | ISBN 9781442622128 (EPUB) | ISBN 9781442622111 (PDF)

Subjects: LCSH: Indigenous peoples - Canada - Public opinion. | LCSH:

Canada - Ethnic relations. | LCSH: Canada - Race relations. | LCSH:

Indigenous peoples - Canada - Social conditions.

Classification: LCC E98.P99 S65 2021 | DDC 305.897/071 - dc23

University of Toronto Press acknowledges the financial assistance to its publishing program of the Canada Council for the Arts and the Ontario Arts Council, an agency of the Government of Ontario.

Canada Council for the Arts

Funded by the Financé par le Government gouvernement of Canada du Canada

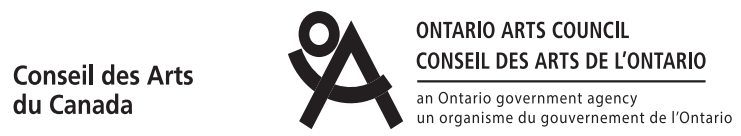

Canadă

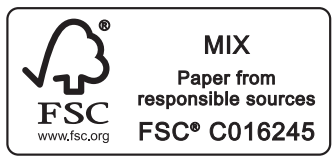


Dedicated to the memory of John F. Leslie (1945-2017), historian, former manager of the Claims and Historical Research Centre at Indian and Northern Affairs Canada, and good friend for over thirty years. 
This page intentionally left blank 